\title{
Human Varicella Zoster Immune Globulin
}

National Cancer Institute

\section{Source}

National Cancer Institute. Human Varicella Zoster Immune Globulin. NCI Thesaurus. Code C123431.

A human plasma-derived immunog lobulin $\mathrm{G}(\lg \mathrm{G})$ formulation containing high levels of antibodies against varicella zoster virus (VZV), a double-stranded DNA virus that causes chickenpox and herpes zoster (shingles), with potential immunomodulating and antiviral activities. VZV IgG (VARIZIG) is isolated from donors expressing high amounts of VZV antibodies. Upon intramuscular (IM) administration, the anti-VZV antibodies provide passive immunization against VZV. This may prevent infection by VZV in immunocompromised patients. 